\section{Milowanov V., Balashov D.}

\title{
IMPROVEMENT OF THERMOTECHNICAL PROPERTIES OF REFRIGERATOR'S EVAPORATOR USING NANOPARTICLES
}

В роботі наведена інформачія про перспективи використання наночасток для покращення теплотехнічних характеристик теплообмінних апаратів холодильної машини, працюючої на ізобутані. Вплив нанодомішок розглянутий на прикладі експериментального дослідження випарника. Об'єктом дослідження є випарник холодильної машини, працюючої у складі калориметричного стенду. Параметрами, на які зверталась увага в експерименті були коефічієнт теплопередачі та коефічієнт тепловіддачі. Одним з найбільи проблемних місиь є використання зразкових манометрів та термометрів, шо вимагали зняття даних вручну. Проблему можна усунути за допомогою заміни аналогових приладів на цифрові з постійним зняттям параметрів та автоматичним занесенням і обробкою їх комп'ютером. Також для встановлення режиму вимагалось багато часу.

В ході дослідження отримані дані, що при використанні нанофлюідів як робочого тіла можливе підвищення коефіцієнта теплопередачі на $21 \%$ при режимі з температурою кипіння $-20^{\circ} \mathrm{C}$ і температурою конденсації $40^{\circ} \mathrm{C}$. А також на 18,1\% при режимі з температурою кипіння - $15^{\circ}$ С. Коефіцієнт тепловіддачі у випарнику вдається підвищити до 7,5\%. Це пов'язано з тим, що запропонований метод внесення часток оксида титана до робочого тіла холодильної машини призводить до підвищення теплопровідності, а отже $і$ до покращення теплопередачі у теплообмінних апаратах. Використання нанофлюідів дозволяє істотно підвищити тепломассообменні характеристики холодоагенту, у порівнянні з засобами, що вимагають конструктивних змін в схемі холодильної машини, зменшити температурні перепади на поверхнях конденсатора і випарника. І в результаті знизити відношення тисків кипіння $i$ конденсащіі, а отже $і$ споживану холодильною машиною електричну потужність без внесення додаткових елементів до апарата. Галузями раціонального застосування даних добавок є підприємства і виробнищтва холодильних машин малої продуктивності, включаючи побутову техніку.

Ключові слова: холодильна машина при роботі на ізобутані, нанодомішка, коефіщієнти теплопередачі та тепловіддачі у випарнику.

\section{Introduction}

International legislation on the removal of ozonedepleting substances from circulation encourages the search for new environmentally safe working substances and additives to existing refrigerants.

The use of nanofluids makes it possible to significantly increase the heat and mass transfer characteristics of the refrigerant, reduce temperature differences on the condenser and evaporator surfaces and, as a result, reduce the ratio of boiling and condensation pressures and, consequently, the electric power consumed by the refrigerator.

From the analysis of information published in the press about the effect of nanomaterials on the work of small refrigerators, it is concluded that most of the work is devoted to the study of the thermal conductivity of substances with nanoparticles dissolved in them. Data on the effect of nano additives on the operation of heat exchangers of a small refrigerators are practically absent in the literature. This makes it difficult to find technical solutions aimed at improving the efficiency of small refrigerators.

Thus, the work on further research of small refrigerators with nanofluids as a working fluid becomes relevant.

\section{The object of research and its technological audit}

The object of research is the refrigerator's evaporator, working as part of the calorimetric stand. The scheme of the test bench is presented in Fig. 1. Compressor 1 injects refrigerant into water condenser 2, from where liquid flows into receiver 3 . Constant boiling pressure in evaporator 10 located in calorimeter 9 is maintained using manual bar regulating valve (BRV) 6. The lower part of the calorimeter is filled with secondary refrigerant 7 , the electric heater 8 is immersed in it. R-134a refrigerant (China) is used as a secondary refrigerant. The vapor generated during boiling condenses on the outer surface of the evaporator 10. During testing, the heater power is controlled so that the pressure of the secondary refrigerant remains constant, that is, the amount of cold produced is equal to the amount of heat added. The scheme includes a viewing glass 5 , a filter drier 4 . The diagram shows the installation location of manometers and thermometers. The pressure of the refrigerant is measured with exemplary manometers of class 0.2 ; temperature of the refrigerant and water - with mercury thermometers with a scale value of $0.1{ }^{\circ} \mathrm{C}$; air temperature - with thermometers with a scale 
value of $0.5^{\circ} \mathrm{C}$. For more precise BRV adjustment, a screw with a fine thread is used.

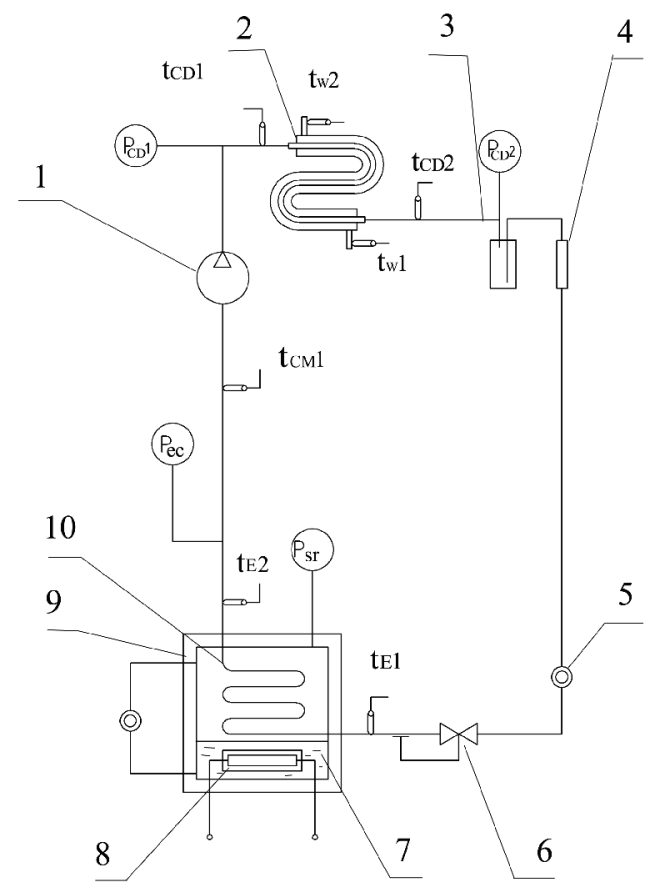

Fig. 1. Scheme of the test bench: $t_{C D 1}, t_{C D 2}$ - thermometers at the inlet and outlet of the condenser; $t_{W 1}, t_{W 2}$ - thermometers in the water line at the inlet and outlet of the condenser; $t_{E 1}, t_{E 2}$ - thermometers at the inlet and outlet of the evaporator; $t_{C M 1}$ - thermometer at the entrance to the compressor; $P_{C D 1}, P_{C D 2}$ - manometers at the inlet and outlet of the condenser; $P_{\text {ec }}$ - manometer at the entrance to the compressor; $P_{s \Gamma}$ - manometer of the secondary refrigerant

The unique properties of nanofluids are increased thermal conductivity, viscosity and heat transfer coefficient. It is known that the thermal conductivity of metals at room temperature is higher than that of liquids. Consequently, the thermal conductivity of a liquid with metal particles is higher than that of a conventional liquid. It is assumed that the Nusselt numbers for nanofluids are higher than those of the base fluid with certain flow parameters (for example, with equal Reynolds numbers) [1]. Elevated Nusselt numbers in combination with higher thermal conductivity give better convective heat transfer compared with the base heat carrier. This will improve the heat and mass transfer characteristics of heat exchangers of the refrigerator without making any structural changes.

One of the most problematic places is the use of model manometers and thermometers, which required manual data removal. The problem can be solved by replacing analog devices with digital ones with constant parameter removal and automatic recording and processing by computer. It also took a long time to establish the regime.

\section{The aim and objectives of research}

The aim of research is studying the effect of nanoparticle additives on the example of the operation of a small refrigerator. As a result of the research, it is planned to obtain the values of the heat transfer and heat transfer coefficients in the heat exchanger apparatus and to compare their values for the net refrigerant and the refrigerant with the addition of nanomaterials.
To achieve this aim, it is necessary to perform the following objectives:

1. Perform a design study of the heat exchangers of the refrigerator when operating on R600a and with additions of different concentrations of nanoparticles.

2. Conduct experimental studies of the performance of a small refrigeratorin various modes of operation on pure R600a and with the addition of different concentrations of nanoparticles.

3. Compare thermotechical parameters of therefrigerator's chiller when working on a pure working body and working body with the addition of nanoparticles.

\section{Research of existing solutions of the problem}

It is possible to reduce the consumption of electricity by a refrigerator by improving the efficiency of heat exchange systems. New heat transfer fluids with improved thermodynamic characteristics are one of the options for improving heat transfer. An important achievement in the study of coolants is the use of a colloidal mixture of the main liquid refrigerant and metal particles 1-100 nanometers in size. The initial versions of colloidal solutions, such as microfluids, led to the formation of a precipitate, which caused erosion of the friction surfaces of metal parts. Nanofluids are uncoupling monoparticles located in the base fluid [2]. Their use can increase heat transfer by more than $50 \%$ in actual heat exchangers of refrigeration units even when the relative volume of nanoparticles is less than $0.3 \%$ [3].

Increased thermal conductivity is a consequence of uniform dispersion of particles. Although thermal conductivity is a function of the basic parameters of a refrigerant, such as pressure and temperature, the effective thermal conductivity in a turbulent flow is much higher due to the influence of turbulent vortices. Increased turbulence is also a consequence of the presence of nanoparticles [4].

The literature presents a large amount of theoretical work on the effective thermal conductivity of two- and more-component materials, for example, the approach of Hamilton and Crosser et al. The form influence factor $n$, which is determined experimentally for different types of materials, is introduced [5]. The aimof their research is development of a model as a function of particle shape, composition and thermal conductivity of both phases:

$$
k_{c}=k_{f}\left[\frac{k_{p}+k_{f}(n-1)-(n-1) V_{p}\left(k_{f}-k_{p}\right)}{k_{p}+k_{f}(n-1)+V_{p}\left(k_{f}-k_{p}\right)}\right],
$$

where $k_{f}$ - coefficient of thermal conductivity of the liquid; $k_{p}$ - coefficient of thermal conductivity of particles; $V_{p}-$ volume fraction of particles; $n$ - factor of influence of the particle shape, derived empirically (for spherical particles $n=3$ ) and is defined as $n=3 / \psi \cdot \psi$ - sphericity, defined as the ratio of the surface area of a sphere with a volume equal to the volume of the particle to the surface area of the particle. The Hamilton-Crosser model reduces to the Maxwell model at $\psi=1$ and is consistent with experimental data for $V_{p}<30 \%$. The model is correct as long as the thermal conductivity of the particles is greater than the thermal conductivity of the liquid, at least 100 times. Although the experiments show that these models are sufficiently suitable for predicting thermal conductivity, they do not take into account the influence of nanoparticle size. 
For the successful practical application of nanofluids, a complete understanding of the processes of forced convection in laminar and turbulent flow is necessary. Nanofluids are essentially multi-component fluids. Consequently, in the literature they are considered either as a two-phase homogeneous flow without sliding between the particles and the liquid, which are also in a state of temperature equilibrium, or with particles sliding relative to the base liquid with temperature equilibrium.

Most streams with forced convection depend on the Reynolds and Prandtl numbers, but in the case of nanofluids, additional parameters are included that take into account the thermal properties of all components. The coefficient of thermal conductivity will depend on the thermal conductivity and heat capacity of the base fluid and nanomaterials, the flow pattern, Prandtl and Reynolds criteria, temperature, volume fraction of dissolved particles, their size and shape.

The following generalization for the Nusselt number [6] is proposed:

$$
\text { Nunf }=f\left[\begin{array}{l}
\operatorname{Re}, \operatorname{Pr}, \frac{K n}{K f} \frac{\left(\rho c_{p}\right)_{n}}{\left(\rho c_{p}\right)_{f}}, \\
\varphi, \text { particle shape, flow geometry }
\end{array}\right],
$$

where $f$ and $n$ denote liquid and nanomaterials, respectively; Re - Reynolds number; Pr - Prandtl number; $K_{n}$ - coefficient of heat conductivity of the particle; $K_{f}-$ thermal conductivity coefficient of the liquid; $\rho$ - density; $c_{p}$ - heat capacity; $\varphi$ - fraction of dissolved particles. Another possible formulation method proposed by the same authors is the assumption that the ratio of the heat transfer coefficients of the nanofluid and the base fluid is proportional to the ratio of the corresponding thermal conductivities of the nanofluid and the base fluid raised to the power of $m$ :

$$
h_{n f} \approx h_{f}\left(\frac{K_{n f}}{K_{f}}\right)^{m},
$$

where $h_{n f}$ - thermal conductivity of the nanofluid; $h_{f}-$ thermal conductivity of the liquid; the exponent $m$ depends on the flow regime and is presumably equal to $2 / 3$ for the turbulent flow.

The methods mentioned above treat a nanofluid as a single-phase fluid, in contrast to reality, where it is a mixture of liquid and solid particles. The size of the dissolved particles brings some difficulties for the analysis of the interaction of liquid and solid particles in the process of heat transfer. Many researchers suggest that the Brownian motion is one of the factors for improving thermal conductivity. This random movement of ultra-small particles adds velocity to the solid particles relative to the liquid. It is also supposed to include small perturbations of temperature and velocity in the consequences of the influence of Brownian motion.

Thus, in the opinion of the authors of [7], a significant change in the thermal conductivity of $\mathrm{Al}_{2} \mathrm{O}_{3}$ or $\mathrm{CuO}$ nanofluids is observed in a small temperature range from 20 to $50{ }^{\circ} \mathrm{C}$. An even stronger effect of temperature is found in the dependence of the thermal conductivity of nanofluids from $\mathrm{Al}_{2} \mathrm{O} 3$ on the particle size in the study [8].

The authors of [9] also show the dependence of thermal conductivity on size. However, the problem with this approach is that research, as a rule, provides only the primary size of nanoparticles. It is well known that particles tend to agglomerate and this process affects the thermal conductivity of the liquid.

It is noted in [10] that the effects of temperature and particle size are so pronounced that they can be taken as criteria for the classification of suspensions as nanofluids.

Nevertheless, information about the properties of nanofluids in scientific literature is often contradictory. For example, in [11], based on the analysis of experimental dependences of thermal conductivity on temperature for nanofluids from three types of metal oxide nanoparticles, it is concluded that they are weak. And that the data for nanofluids $\mathrm{CuO}+\mathrm{H}_{2} \mathrm{O}$ that do not correspond to this statement are not a specific feature of nanofluids, but an accidental exception.

\section{Methods of research}

The criteria for which the calculation is carried out, are defined as:

$$
\begin{aligned}
& \operatorname{Pr}=\frac{\mu_{\text {eff }} c_{p, e f f}}{K_{\text {eff }}} ; \\
& \operatorname{Re}=\frac{\rho_{\text {eff }} u d}{\mu_{\text {eff }}} ; \\
& N u=\frac{h d}{K_{\text {eff }}},
\end{aligned}
$$

where $\mu_{\text {eff }}$ - effective viscosity; $c_{p \text {,eff }}$ - effective heat capacity; $K_{\text {eff }}$ - effective heat transfer coefficient; $\rho_{\text {eff }}$ - effective density; $u$ - flow velocity; $d$ - diameter of the pipe; $N u-$ Nusselt number.

For example, for a fully developed laminar flow with boundary wall temperature conditions:

$$
N u_{T}=\frac{h d}{K_{\text {eff }}}=3.657 .
$$

For a turbulent flow there is a Petukhov-Kirillov correlation:

$$
N u=\frac{h d}{K_{e f f}}=\frac{\left(\frac{f}{8}\right) \operatorname{Re} \cdot \operatorname{Pr}}{\left.1.07+12.7 \sqrt{\left(\frac{f}{8}\right)} \operatorname{Pr}^{2 / 3}-1\right)} \cdot\left(\frac{\mu_{b}}{\mu_{w}}\right)^{n},
$$

where $n=0.11$ for $T_{\text {weall }}>T_{\text {liquid }}, n=0.25$ for $T_{\text {wall }}<T_{\text {liquid }} ; \mu_{b}-$ nanofluid viscosity; $\mu_{w}$ - viscosity of pure liquid.

$$
f=(1.82 \lg \operatorname{Re}-1.64)^{-2} .
$$

The correction can be used to calculate heat transfer coefficients for flow in a channel for laminar and turbulent flows, respectively, using the appropriate properties of nanofluids. Results can be comparable with experimental ones under the same conditions.

The classical Graetz solution for an equation with an ideal flow, $u=$ const, for the boundary conditions of constant wall temperature [12]. 


$$
\begin{aligned}
& N u_{x}=\frac{h_{x} d}{K}=\frac{\sum_{m=1}^{\infty} e^{-4 \lambda_{m}^{2}(x / d) / P e}}{\sum_{m=1}^{\infty} \frac{1}{\lambda_{m}^{2}} e^{-4 \lambda_{m}^{2}(x / d) / P e}} ; \\
& P e=\frac{U_{m} d}{\alpha_{e f f}^{*}},
\end{aligned}
$$

where $x$ - length of the calculated area; $P e$ - Peclet number; $\alpha$ - thermal diffusivity.

The classical Graetz equation can be extended for the boundary conditions of constant heat flow, constant wall temperature and linear wall temperature with a parabolic velocity profile. Using a parabolic velocity profile, we obtain local Nusselt numbers:

- constant wall temperature:

$$
N u_{x}=\frac{h_{x} d}{K_{e f f}}=\frac{\sum_{n=1}^{\infty} A_{n} e^{-\lambda_{n}^{2} \xi}}{\sum_{n=1}^{\infty} \frac{A_{n}}{\lambda_{n}^{2}} e^{-\lambda_{n}^{2} \zeta}},
$$

where $A$ - correction for the flow profile;

- constant heat flow:

$$
N u_{x}=\frac{h_{x} d}{K_{\text {eff }}}=\left[\frac{11}{48}-\frac{1}{2} \sum_{n=1}^{\infty} \frac{e^{-\beta_{n}^{2} \zeta}}{A_{n} \beta_{n}^{4}}\right]^{-1},
$$

where $\beta$ - linear expansion coefficient;

- linear wall temperature:

$$
N u_{x}=\frac{h_{x} d}{K_{e f f}}=\frac{\frac{1}{2}+4 \sum_{n=1}^{\infty} \frac{C_{n}}{2} \cdot \frac{R_{n}^{\prime}(1)}{\lambda_{n}^{4}} e^{-\lambda_{n}^{2} \zeta}}{\frac{11}{96}+8 \sum_{n=1}^{\infty} \frac{C_{n}}{2} \cdot \frac{R_{n}^{\prime}(1)}{\lambda_{n}^{4}} e^{-\lambda_{n}^{2} \zeta}},
$$

where $\zeta=\frac{x / r_{0}}{P e}, P e=\frac{u_{m} d}{\alpha_{e f f}}$.

For the theoretical calculation, an evaporator of a small refrigerator operating on isobutane as part of a calorimetric test bench is taken. The evaporator is a copper pipe with a diameter of $10 \mathrm{~mm}$, placed in a sealed heat-insulated container, in which there is a secondary refrigerant, which gives off heat generated by an electric heater that simulates the heat load. Calculations are carried out at modes with boiling points $-20,-10,-5$, $0{ }^{\circ} \mathrm{C}$ and condensing temperature $40{ }^{\circ} \mathrm{C}$. Nanoparticles of titanium oxide in a mass concentration of $2.54 \%$ were taken as additives.

For the experiment, Reniso ONF46 oil (Germany) is chosen with the addition of $2.54 \%$ $\mathrm{TiO}_{2}$ nanoparticles. To destroy nanoparticle clusters, the sample is homogenized using an ultrasonic disperser at room temperature for 30 minutes. To isolate a precipi- tate of nanoparticle clusters, the sample is centrifuged for 45 minutes.

A $350 \mathrm{ml}$ oil refill is removed from the compressor designed for testing and replaced with Reniso ONF46 pure oil, after which experiments are carried out to determine the parameters of the refrigeration unit in different modes. After completion of the experiments, the pure oil is removed from the system and replaced with a nano-oil with a mass concentration of $\mathrm{TiO}_{2}$ particles of $2.54 \%$, after which the experiments to determine the parameters are repeated in the same modes.

Thermal load of the evaporator:

$$
Q_{e}=Q_{\text {heat }}-Q_{i}=U \cdot I-Q_{i},
$$

where $Q_{e}$ - heat given off by the evaporator; $Q_{\text {heat }}$ - heat, given by the heater; $Q_{i}$ - heat loss through insulation; $U-$ voltage; $I$ - amperage.

\section{Research results}

In the course of the experiment, a decrease in the temperature difference in the evaporator was observed under all conditions, which led to the conclusion about the effect of nano additives on the heat-transfer characteristics of the apparatus.

Fig. 2 shows the temperature of the secondary refrigerant in the calorimeter-evaporator. With known values of heat given up through the electric heater $Q$ (determined from wattmeter readings), the known surface area of the heat exchanger $F$ and the known temperature head $\Delta T$ from the basic heat transfer equation $Q=k F \Delta T$, it is possible to determine the value of heat transfer coefficient $k$.

Fig. 3 shows the heat transfer coefficients in the evaporator, determined experimentally. An increase in the heat transfer coefficient is observed when using the nanorefrigerant.

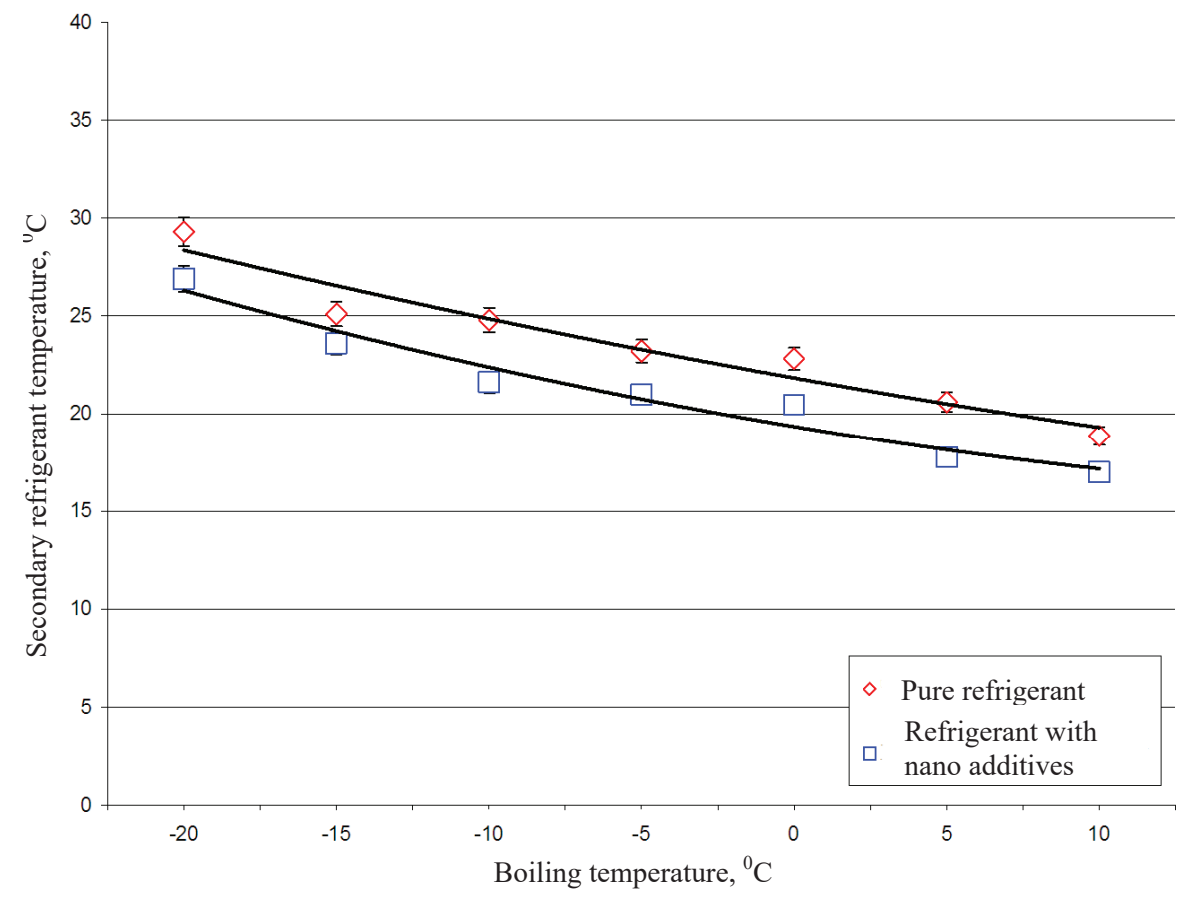

Fig. 2. Evaporator temperatures 


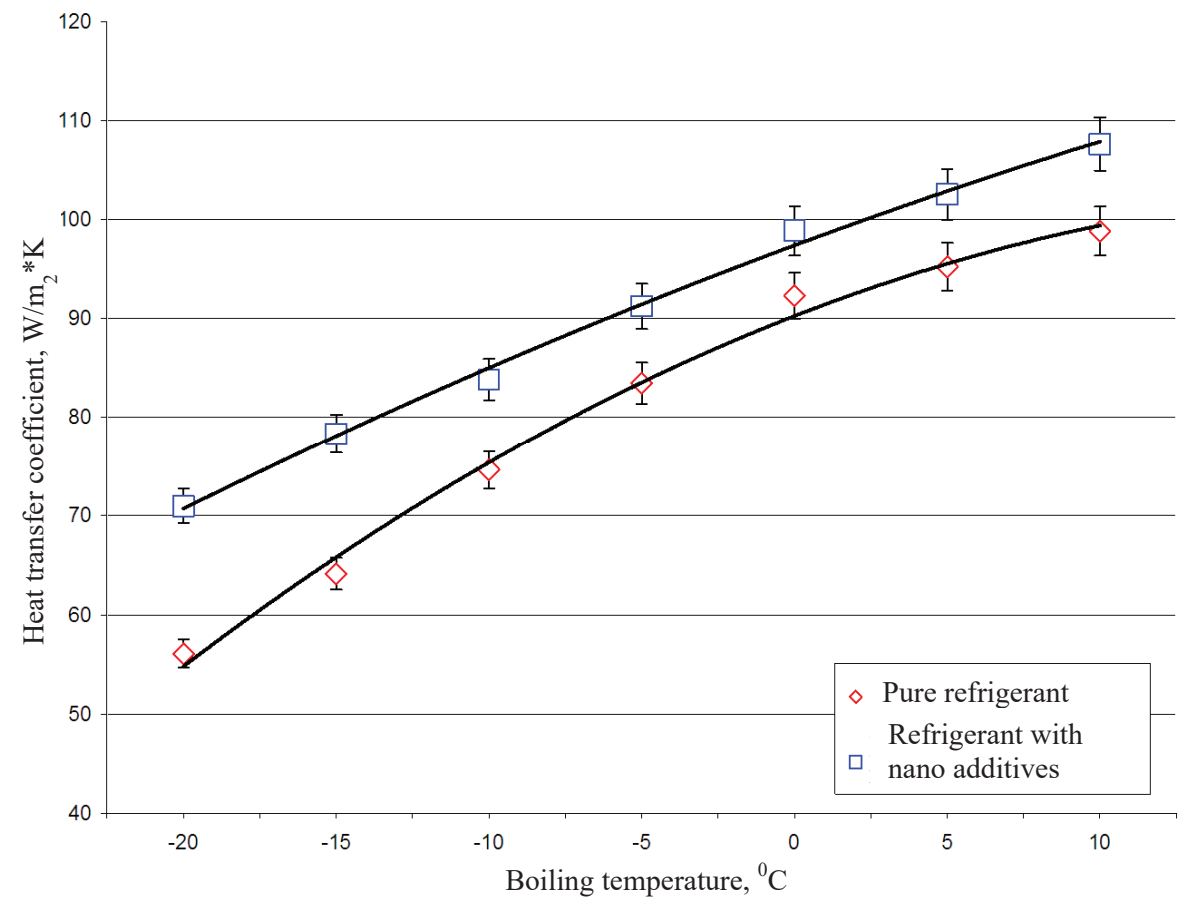

Fig. 3. Heat transfer coefficients in the evaporator

At equal heat load and constant structural parameters of the evaporator, it can be concluded from this that with the use of nanorefrigerant there is an increase in the heat transfer coefficient. Increasing the heat transfer coefficient of the evaporator makes it possible to transfer a greater amount of heat through the same surface area. The deviation of the experimental results from the theoretical calculation does not exceed $5 \%$, which shows sufficient accuracy of the calculation. From the formula for calculating the heat transfer coefficient, it is necessary to determine the value of the heat transfer coefficient $\alpha_{1}$ :

$$
k=\left(\begin{array}{l}
\frac{1}{\alpha_{1} d_{1}}+\frac{1}{2 \lambda} \times \\
\times \ln \frac{d_{2}}{d_{1}}+\frac{1}{\alpha_{2} d_{2}}
\end{array}\right)^{-1},
$$

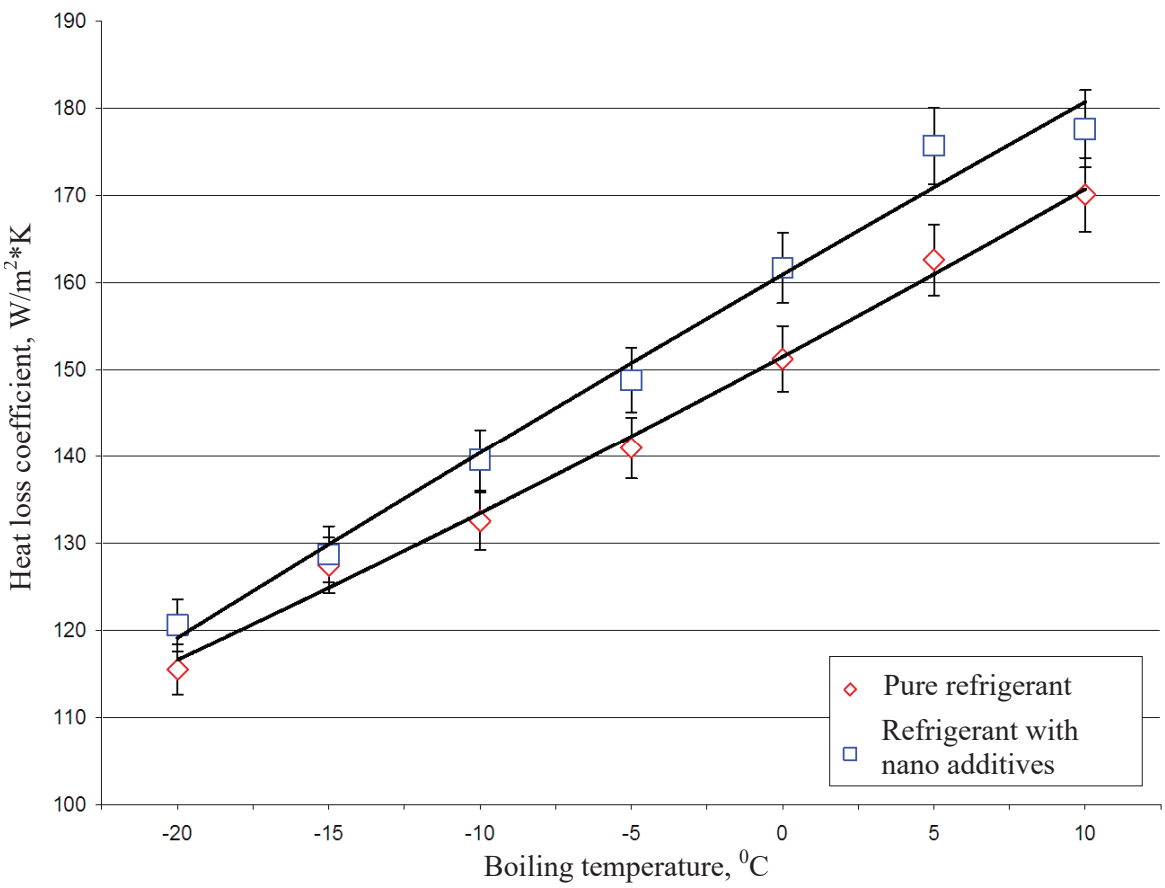

Fig. 4. Heat loss coefficients in the evaporator

where $\alpha_{1}$ - heat loss coefficient from the refrigerant; $\alpha_{2}-$ heat loss coefficient from the secondary refrigerant; $d_{1}-$ diameter of the inner wall of the pipe; $d_{2}$ - diameter of the outer wall of the pipe.

The amount of heat transferred and the heat loss coefficient $\alpha_{2}$ from the secondary refrigerant are known. The thermal resistance of the pipe wall has not changed. The results of the calculation of the heat loss coefficient are presented in Fig. 4.

Table 1 shows the heat transfer coefficients from the side of the refrigerant with a pure refrigerant and with nano additives.

Change in heat loss and heat transfer coefficients in the evaporator

\begin{tabular}{|l|c|c|c|c|c|c|c|}
\hline \multirow{2}{*}{ Parameter } & \multicolumn{6}{|c|}{ Boiling temperature, ${ }^{\circ} \mathrm{C}$} \\
\cline { 2 - 8 } & -20 & -15 & -10 & -5 & 0 & 5 & 10 \\
\hline $\begin{array}{l}\text { Change in heat loss coeffi- } \\
\text { cient, \% }\end{array}$ & 4.2 & 1 & 5 & 5.3 & 6.4 & 7.5 & 4.3 \\
\hline $\begin{array}{l}\text { Change of heat transfer coef- } \\
\text { ficient, \% }\end{array}$ & 21 & 18.1 & 8.4 & 8.5 & 6.9 & 7.1 & 8.2 \\
\hline
\end{tabular}


The increase in heat loss coefficient occurs evenly in all modes. From this it is possible to conclude that the use of additives of nanoparticles can improve the heat exchange characteristics of the apparatus of refrigerators, while not requiring structural changes.

\section{SWOT analysis of research results}

Strengths. The use of nanofluids allows to significantly increase the heat and mass transfer characteristics of the refrigerant, to reduce the temperature drops on the surfaces of the condenser and the evaporator. And as a result, to reduce the ratio of boiling and condensing pressures, and, consequently, the electric power consumed by the refrigerator.

Weaknesses. Dispersion of nanoparticles in a liquid leads to increased viscosity, which is influenced by the average particle diameter, concentration and temperature. Increased viscosity reduces the Reynolds number in comparison with the base fluid at the same speed. These factors must be weighed in assessing the applicability of nanofluids as a refrigerant.

Opportunities. The use of nano additives is also promising in home refrigerators, commercial and industrial equipment. Prospects for the use of nanofluids as additives in refrigerants of modern refrigerators are obvious, but this problem requires further study, analysis, theoretical and experimental studies, especially in the field of high boiling points.

Threats. Currently, a large number of studies are being conducted on the use of nanomaterials in refrigeration and compressor technology. The use of nanoparticles such as fullerenes or carbon nanotubes can further improve the thermophysical characteristics of refrigerants, as well as reduce friction power in the compressor, which titanium oxide nanoparticles are not capable of, the effect of which is considered in this paper.

\section{Conclusions}

1. A calculated study of the evaporator of the refrigerator is done. The results show that with the use of nanofluids as a working fluid, an increase in the heat transfer coefficient of $21 \%$ is possible with a regime with a boiling point of $-20^{\circ} \mathrm{C}$ and a condensation temperature of $40{ }^{\circ} \mathrm{C}$. And also by $18.1 \%$ at the mode with boiling point $-15{ }^{\circ} \mathrm{C}$.

2. The use of nanorefrigerant as a working fluid allows to increase the heat exchange characteristics of the apparatus of the refrigerator without their structural changes. Experimental studies have shown that the use of a refrigerant with a mass concentration of nanoparticles of $2.54 \%$ can increase the heat transfer coefficient in the evaporator to $21 \%$, and the heat loss coefficient to $7.5 \%$.

3. Comparison of the thermotechnical parameters of the refrigerator's evaporator when working on a pure working body and working body with the addition of nanoparticles shows that the discrepancy between the results of theoretical and experimental research is not more than $5 \%$. This indicates the correctness of the chosen method of calculation and the possibility of further predicting the parameters with its help.

\section{References}

1. Saidur R., Leong K. Y., Mohammad H. A. A review on applications and challenges of nanofluids // Renewable and Sustainable Energy Reviews. 2011. Vol. 15, Issue 3. P. 1646-1668. doi: http://doi.org/10.1016/j.rser.2010.11.035

2. Choi S. U. S., Eastman J. A. Enhancing thermal conductivity of fluids with nanoparticles // Conference: 1995 International mechanical engineering congress and exhibition. San Francisco, 1995. URL: http://www.osti.gov/scitech/servlets/purl/196525

3. Strandberg R., Das D. K. Finned tube performance evaluation with nanofluids and conventional heat transfer fluids // International Journal of Thermal Sciences. 2010. Vol. 49, Issue 3 P. 580-588. doi: http://doi.org/10.1016/j.ijthermalsci.2009.08.008

4. Xuan Y. Li O Investigation on Convective Heat Transfer and Flow Features of Nanofluids // Journal of Heat Transfer. 2003. Vol. 125 Issue 1. P. 151-155. doi: http://doi.org/10.1115/1.1532008

5. Hamilton R. L., Crosser O. K. Thermal Conductivity of Heterogeneous Two-Component Systems // Industrial \& Engineering Chemistry Fundamentals. 1962. Vol. 1, Issue 3. P. 187-191. doi: http://doi.org/10.1021/i160003a005

6. Xuan Y., Roetzel W. Conceptions for heat transfer correlation of nanofluids // International Journal of Heat and Mass Transfer. 2000. Vol. 43, Issue 19. P. 3701-3707. doi: http:// doi.org/10.1016/s0017-9310(99)00369-5

7. Li C. H., Peterson G. P. Experimental investigation of temperature and volume fraction variations on the effective thermal conductivity of nanoparticle suspensions (nanofluids) // Journal of Applied Physics. 2006. Vol. 99, Issue 8. P. 084314. doi: http://doi.org/10.1063/1.2191571

8. Li C. H., Peterson G. P. Mixing effect on the enhancement of the effective thermal conductivity of nanoparticle suspensions (nanofluids) // International Journal of Heat and Mass Transfer. 2007. Vol. 50, Issue 23-24. P. 4668-4677. doi: http:// doi.org/10.1016/j.ijheatmasstransfer.2007.03.015

9. Chon C. H., Kihm K. D. Thermal Conductivity Enhancement of Nanofluids by Brownian Motion // Journal of Heat Transfer. 2005 Vol. 127, Issue 8. P. 810. doi: http://doi.org/10.1115/1.2033316

10. Das S. K., Choi S. U. S., Patel H. E. Heat Transfer in Nanofluids A Review // Heat Transfer Engineering. 2006. Vol. 27, Issue 10. P. 3-19. doi: http://doi.org/10.1080/01457630600904593

11. Kim S. H., Choi S. R., Kim D. Thermal Conductivity of MetalOxide Nanofluids: Particle Size Dependence and Effect of Laser Irradiation // Journal of Heat Transfer. 2007. Vol. 129 Issue 3. P. 298-307. doi: http://doi.org/10.1115/1.2427071

12. Measuring Thermal Conductivity of Fluids Containing Oxide Nanoparticles / Lee S., Choi S. U.-S., Li S., Eastman J. A. // Journal of Heat Transfer. 1999. Vol. 121, Issue 2. P. 280-289. doi: http://doi.org/10.1115/1.2825978

Milowanov Valery, Doctor of Technical Sciences, Professor, Head of Department of Compressors and Pneumounit, V. S. Martynovskyi Educational and Scientific Institute of Cold, Cryotechnologies and Environmental Energy, Odessa National Academy of Food Technologies, Ukraine, ORCID: http://orcid.org/0000-0003-0776-5164

Balashov Dmitriy, Engineer, V. S. Martynovskyi Educational and Scientific Institute of Cold, Cryotechnologies and Environmental Energy, Odessa National Academy of Food Technologies, Ukraine, e-mail: balashov_d@ukr.net, ORCID: http://orcid.org/0000-00019950-2200 